\title{
A bet for Brazil
}

Brazil is marked by recurrent crises that reflect traces of the colonization, an inheritance of a backward, conservative and self-referential elite that perpetuates the culture of the 'casa grande and senzala' (the masters and the slaves). Stumbling over successive crises throughout its history, the current crisis demands that we join forces to face the interests of the actors and projects that are behind the parliamentary coup.

From that perspective, it is imperative to reflect on some questions: what is the possibility of a social pact that will take Brazil out of the crisis? What to expect from the national political and economic elites in the current political scenario? Are the possibilities for a democracy that materializes social rights as a strategy against this crisis still alive? How to build alternative paths for a Brazil with social justice?

In the process of redemocratization that took place in the 1980s, the ideas of a welfare state prevailed and prospered in the Constituent Assembly. Even if late in relation to European countries, this model of state assures Brazilians of universalist social rights and policies, that is, it includes the population historically excluded from the sharing of the wealth produced by labor and appropriated by the capital and the State. If on the one hand the sharing that has always favored a small part of the population legitimized the exploitation of labor, on the other hand, it is responsible for both the origin and the deepening of social inequalities.

It is important to recover the mechanisms that made possible the constitutional advances at this moment that calls for concrete and efficient strategies of resistance and struggle against the fatalistic tendency that is immobilized in the face of the current configuration of the National Congress and the Powers in general.

Without disregarding that we have today the most conservative composition of Congress since the military regime, it can not be said that at some point in history 'the People's House' has been effectively progressive. The Constituent Congress that produced the Citizen Constitution had only $5 \%$ female parliamentarians, $4 \%$ were under 30 years of age and more than $70 \%$ had higher education. In addition, $32 \%$ were entrepreneurs, and only $12 \%$ were civil servants.

According to research in a newspaper of the time, elected in the light of the popular mobilization for direct elections that shook the Country, $32 \%$ of the congressmen self-define as center, $24 \%$ as center-right and $12 \%$ as right-wing, totaling a large majority of $68 \%$ of parliamentarians with a center-right tendency. In that political context, some questions permeate History: how did the Constitution of 1988 manage to incorporate social rights, universalist policies and many other advances? How was the expression of the conservative majority of the Constituent Congress barred?

One of the strong reasons was undoubtedly the presence of the recent memory of the popular force mobilized by changes. Besides that, the political action of leaders and activists 
- and the Sanitary Reform Movement is exemplary -, popular representations installed in the political scenario acting by pressure and carrying out permanent dialogue with constituent parliamentarians.

There was an atmosphere of negotiation and there were legislators who felt it was their job to listen to the yearnings of society and to build agreements between the different political and economic forces. In this dynamic of social struggles, it was possible to negotiate even with conservative patrimonialist forces, which have always treated the Brazilian State as if it were theirs.

The amalgam of this 'Social Pact' was the feeling that it was time to pay the enormous social debt accumulated since colonial times, deepened during the military dictatorship.

Recovering the recent history of left-wing culture is useful to strengthen arguments for resistance and convince that the fight is not lost. It serves to reflect and conclude that, perhaps, what we have been lacking is concrete political action, politicization, face-to-face discussion and strengthening of arguments. A change of language and of tactics to mobilize and make political pressure. More action on the real politics.

However, examining History is indispensable to realize that the interests of class were not exhausted with the Constitutional Pact, on the contrary, it was soon noticed the beginning of an offensive of the conservative classes. After the promulgation of the Constitution, the economic and political elites mobilized by changes in the Magna Carta resulting in the actual disfiguration of its character as a parameter of universal welfare.

The fact is that those political and economic elites have never defended citizenship and social rights. Throughout these three decades, they invest in the restitution of the previous order to guarantee a State that legitimizes capitalist accumulation, ensuring the low cost of labor, no matter how much it generates poverty and increases social, economic and cultural inequalities.

If in the recent moments of prosperity all have gained - some much more than others promoting an apparent and fanciful harmony between classes and fractions of classes, which allowed the State to implement redistributive social policies in times of crisis, what they intend is to assure the gains. Thus, the permanent pact between the political elite and the economic bourgeoisie is resumed to restore the neoliberal market model, with unprecedented attacks on achieved rights, like the offensive of labor and social security reforms.

As recent history has shown, it is not possible to build a pact between the groups that proclaim for 'not one right less' with those who defend 'not one penny less.' It is the confrontation of those interests that can lead to an exit for the Country. It is through the political way, and not through the guts of the crisis or of the groups that are satisfied by it, that we must look for alternatives. For that, the aggregation and unity of forces whose minimum filter must be the commitment to the interests of the public, the people and the pólis.

The central point of analysis must recognize that the structural trait of contemporary capitalism is that the market and the financial system have been engaging in unbridled orgies, pushing the productive system to rock bottom. In such context, there is no more possibility of accumulating capital in the productive economy, and, thus, the value of the labor force is discarded. The absolute capture of the Brazilian State by the interests of the financial system erodes any possibility of advancement of the popular clamor for development and social justice. Reestablishing a political environment of democratic mobilization and dismantling this hegemony imposed on the Country, guaranteeing the popular interests, constitute challenges for the resistance in March.

The most significant character of this resistance is the current retaking of the streets by 
the organized masses in defense of the republican reconstruction, with participatory democracy, it is worth to say, in the tradition of direct democracy. The innovation is precisely the unity between forces that bring together social movements, trade unions, intellectuals and important parts of society. Today, the prevailing sentiment is that of unity, which is considered necessary to change the course of the economy, to prevent setbacks and to reestablish the institutions and practice of democracy.

The presence of the trade union movement for the political struggle must be celebrated. We realize that, every day, groups of political action are coming up all over the Country mobilized by the conviction that the policy of the broad front is the alternative to interrupt the national deconstruction and to carry out a national-popular project.

In response to the movement and mobilization of society, the installation in the Frente Suprapartidária pelas Diretas Já (Supra-partisan Front for Direct Elections Now) in the House of Representatives is of the greatest significance, constituted by parliamentarians affiliated with the most diverse parties and committed to the most diverse currents of thought.

We celebrate the politics of a popular bloc and of the left, transiting and mobilizing local nuclei of political action. It is the pedagogy of the praxis carried out by political fronts, such as the People without Fear Front and the Popular Brazil Front, built by the gathering of parties, trade union centrals and social movements by unity of the popular field. If the crisis has been contributing to the inclusion of progressive forces, it has also been demonstrating, day after day, the illegitimacy of political representation, both at the Legislative and Executive levels. The House and the Senate dedicate to destroying, in admirable of speed, what is still left of the Social State and the Nation. Led by an illegitimate coup president, the Executive sinks into its own inexhaustible moral disorder. In that context, the impartiality of the Judiciary is also unclothed, destroying the hopes for justice, even if historically such power is not characterized as anything other than conservatist.

The conservative contribution of the big press in Brazil imposes its own project fundamented on the monopoly of a single line of thought, transforming itself into a powerful trench of ideological struggle of the rentier capital.

From the fulcrum of the illegitimacy of those powers, arises the anti-national coalition that has undermined the government and holds the majority support of the economic power, demanding 'reforms' charged by the rentier capital, at any cost and regardless of the political framework. For them, democracy and legitimacy are mere abstractions tolerated only when placed at the service of the interests of the bourgeoisie and the dominants.

Let there be clarity as to the scale of the struggle that the Brazilian people will have to strive to guarantee another project of Country and of future. In addition to combating and removing the usurpers from the executive branch, the front must secure new elections. Only a legitimate president supported by social movements can, as the Popular Brazil Front points out, promote

[...] the structural reforms necessary to break with the model of dependent capitalism that has produced, among other sores, the impoverishment of workers, especially of female workers and the black population, extreme social injustice, loss of independence and economic recession, while concentrating income, wealth and property in the hands of a handful of barons of the capital. (POPULAR BRAZIL FRONT, 2017, P. 1).

It will not be enough, however, to carry out these difficult tasks from now on. A political 
reform is necessary. Only the political consciousness that spreads among the people will be a tool for changes in the National Congress, essential for advancing in projects of change. For now, 'Temer Out' and the 'Direct Elections Now', adding the indispensable 'Not one Right Less', are the starting points!

Unity of forces in favor of Brazil and our people!

Ana Maria Costa

Director of the Brazilian Center for Health Studies (Cebes) and associate editor of 'Saúde em Debate'

Maria Lucia Frizon Rizzotto

Director of the Brazilian Center for Health Studies (Cebes) and of 'Saúde em Debate'

\section{Reference}

FRENTE BRASIL POPULAR. Plano Popular de Emergência. São Paulo: Frente Brasil Popular, 2017. Disponível em: <http://frentebrasilpopular.org.br/ acao/plano-popular-de-emergencia-5b24/?f=023eb5 aa9339ca54a70eea25e3ecf069\#down>. Acesso em: 4 jul. 2017. 